\title{
PREDICTING THE LIFE SATISFACTION OF INDONESIAN CHRISTIAN EMPLOYEES: EXAMINING THE ROLE OF RELIGIOSITY, PERCEIVED ORGANIZATIONAL SUPPORT, AND MEANINGFUL WORK
}

\author{
Yusak Novanto ${ }^{1,2}$, Seger Handoyo ${ }^{1}$, \& Jenny Lukito Setiawan ${ }^{3}$ \\ ${ }^{I}$ Fakultas Psikologi, Universitas Airlangga, Jl. Airlangga 4-6, Surabaya 60286, Indonesia \\ ${ }^{2}$ Fakultas Psikologi, Universitas Pelita Harapan, Jl. M.H. Thamrin Boulevard 1100, Lippo Village, Tangerang, Banten 15811, Indonesia \\ ${ }^{3}$ Fakultas Psikologi, Universitas Ciputra, CitraLand CBD Boulevard, Surabaya 60219, Indonesia
}

Correspondence: yusak.novanto-2015@psikologi.unair.ac.id,yusak.novanto@uph.edu

\begin{tabular}{lcccccc}
\hline MEMPREDIKSI KEPUASAN HIDUP & KARYAWAN KRISTEN DI & Manuscript type: Original Research \\
INDONESIA: & MENGUJI PERAN RELIGIOSITAS, PERSEPSI &
\end{tabular}

DUKUNGAN ORGANISASI, DAN MAKNA KERJA

\section{Abstrak}

Kepuasan hidup individu berperan penting dalam peningkatan kinerja dan berkaitan dengan religiositas, serta persepsi individu terhadap dukungan organisasi dan makna kerjanya. Penelitian ini bertujuan untuk menganalisis pengaruh religiositas dan persepsi dukungan organisasi terhadap kepuasan hidup melalui makna kerja sebagai variabel mediator pada 263 partisipan dari 118 organisasi di Indonesia. Sebagian besar partisipan (71.86\%) merasa puas dengan kondisi kehidupannya. Hasil penelitian ini juga menunjukkan bahwa makna kerja dapat menjadi variabel mediator secara parsial pengaruh religiositas dan persepsi dukungan organisasi terhadap kepuasan hidup. Studi ini menyimpulkan bahwa pimpinan organisasi dapat mengimplementasikan kegiatan kerohanian dan menunjukkan dukungan dari organisasi untuk meningkatkan kepuasan hidup karyawan Kristen di Indonesia.

Article history:

Received 8 September 2020

Received in revised form 1 December 2020

Accepted 27 January 2021

Available online 16 July 2021

\section{Kata Kunci:}

karyawan Kristen

kepuasan hidup

makna kerja

persepsi dukungan organisasi

religiositas

\begin{abstract}
Life satisfaction plays important role in employees' work performance and is related to the internal factors of religiosity, perceived organizational support, and meaningful work. This research aims to investigate the influence of religiosity and perceived organizational support on life satisfaction through meaningful work as a mediator for 263 respondents from 118 organizations in Indonesia. This research found that a significant number of participants $(71.86 \%)$ were satisfied with their life. The findings show that religiosity and perceived organizational support enhance their life satisfaction such that meaningful work is a partial mediator for these relationships. Organization leaders should maintain employees' life satisfaction through religious activities and provide them with organizational support.
\end{abstract}

Keywords: Christian employees, life satisfaction, meaningful work, perceived organizational support, religiosity

\section{Impact and Implication in the Indigenous Context}

Christianity is the second largest religion in Indonesia. Christian communities are spread unequally across the country with a large community in the region of Sumatera, Kalimantan, Sulawesi, and Eastern Indonesia. Research on Christian employees in Indonesia from a psychological point of view has not been done much. This research illuminates the effect of religiosity and perceived organizational support on individual's life satisfaction. Through the meaningful work as a mediator variable. The findings contribute to an understanding of intersection between religiosity and work life - in this case, for Christian employees in Indonesia who work in various organizations. This research also provides an indigenous point of view for contextualizing psychological theories and previous research on meaningful work and life satisfaction, which are predominantly from a Western perspective. 


\section{INTRODUCTION}

The era of globalization and the availability of information requires an increase in the quality of human resources to make them superior, competent, professional, and highly competitive (Isjoni, 2006). Organizations or companies that train their human resources must also function as agents of change in the positive transformation of society. From an organizational point of view, institutions must also attend to the life satisfaction and welfare of their human resources (NEF Consulting, 2014). According to the International Organization for Standardization (2018), an organization is considered to have good occupational health and safety systems if they attend to their employees' wellbeing.

Life satisfaction is a goal for all people, and this includes Christian employees who are employed by companies or organizations in Indonesia. One important factor that determines personal life satisfaction is "the world of work". According to Diener et al. (2003), "life satisfaction" is an overall assessment of someone' condition, comprising a person's cognitive perceptions of the comparison between their actual living conditions and the standard of living to which they aspire. Diener et al. (2003) also argued that those with high life satisfaction will have a clear purpose in life and make an effort to achieve it. These individuals also usually have close relationships with family, are supported by friends and spouses, have meaningful activities and jobs, enjoy recreation, and are in good health. Argyle (2001) stated that those who have jobs will feel more satisfied in life than those without jobs. Life satisfaction can describe conditions for people who have a zest for life and have the ability to adapt to various internal/individual and external/environmental changes (Zhou \& Lin, 2016).

Previous research has found that the influences on personal life satisfaction can be broadly divided into three. The first is life events (including income and marital status), the second is intentional activities, and the third is the cognitive disposition and personality of the individual (Puente-Díaz \& Cavazos, 2013). According to Compton (2005), the factors influencing life satisfaction are religiosity, positive self-esteem, sense of perceived control, extraversion, optimism, positive social relationships, social support, self-efficacy, and a sense of meaning and purpose in life. In the Indonesian context, such research on a large number of employees in Christian communities has never been done; the findings for this may be different from studies of others, especially in the meaning-making process attached to individual professions and organisational support. 
One psychological factor and daily activity related to an individual's life satisfaction is that person's level of religiosity (Kate et al., 2017). Employee satisfaction at work can be improved through programs that develop spirituality and religiosity in the workplace (Neal, 2012). An organization that focuses on human resource development should pay more attention to internal factors that can balance the strength of an organization-factors such as life values, emotional maturity, moral development, spirituality, religiosity, and self-understanding (Astin, 2004). Sukarsa (2010) proposes three important things that can build spirituality in the workplace: meaningful work, respecting employees' abilities and creativity, and making the world better for everyone.

Hadjam and Nazirrudin (2003) defined religiosity as the tendency of individuals to view all events and situations in life - both positive and negative - as a unity which is always connected with the overall value of living with God. Glock and Stark's (1965) concept of religiosity comprises religious beliefs (ideological dimension), religious practices (ritual dimension), religious feelings (dimension of experience), religious knowledge (intellectual dimension), and religious influence (dimension of effect).

Argyle (2001) found that religiosity helps individuals maintain their psychological health through difficult times. Furthermore, Arglye (2001) advanced two ways in which religiosity can support the psychological well-being of individuals in difficult times. The first is through social support obtained from their religious community, such as the close ties and bonding between church members within a Christian community. The second is by helping individuals find meaning in the events they experience-for example, that accidents are not merely coincidental but are interpreted as God helping the individual overcome the accident.

Another independent variable examined in this study is the perception of organizational support (POS), which is the general belief of members in an organization that it values their contributions and cares about their lives (Rhoades \& Eisenberger, 2002). If employees consider that they receive high organizational support, then they will assimilate their membership of the organization as a part of their identity, thus developing a more positive relationship and perception of the organization. By internalising organizational membership into their identity, the employee feels part of the organization and therefore responsible for contributing and giving their best performance to it (Rhoades \& Eisenberger, 2002).

Valentine et al. (2006) explain that perceptions of organizational support can be related to ethical contexts and work responses, especially job satisfaction. An organization can improve work attitudes that support its goal by increasing its ethical value. Until now, research on the perception 
of organizational support has generally focused on the relationship between perceived organizational support and organizational commitment, leader-member exchange, and job satisfaction. Previous research on the effect of POS on the life satisfaction of kindergarten teachers in Jakarta showed that it, together with transformational leadership and job satisfaction, influenced their life satisfaction by $65 \%$ (Bachtiar et al., 2018). Therefore, this research included the effect of POS on the life satisfaction of Christian employees in Indonesia.

The last variable examined in this study is meaningful work, which occurs when people feel comfortable with their work and do not regard it as a burden. Giving meaning to our work is a personal process as it relates to perceptions that tend to be subjective, considering each person's different background. Thus, what is valuable in situations and difficulties is determined by each individual. Without discovering meaningful work, individuals cannot see the benefits of their work under any circumstances (Steger \& Dik, 2009).

Steger, Dik, and Shim (2012) labelled the concept of meaning in the context of work as "meaningful work". This is an umbrella for such concepts such as work meaning, work meaningfulness, and positive connotations arising from this (Steger, Dik, \& Shim, 2012). Moreover, Steger and Dik (2009) found that meaningful work has three key facets: positive meaning in work, meaning making through work, and better motivation.

Meaningful work is directly related to the individual life satisfaction of employees of organizations because everyone undergoes a psychological process to give meaning to their respective work before evaluating their current life satisfaction (Frankl, 1984). The process of interpreting work as a meaningful activity ("meaningful work") is one of the factors that affects life satisfaction. Doing a job that is in harmony with a person's skills, interests, and values will increase the meaning of work, ultimately affecting personal life satisfaction (Erdogan et al., 2012).

In this research, meaningful work was tested as an intervening variable that functions as a mediator of the relationships between exogenous and endogenous variables. There is a paucity of research in Indonesia that analyzes the effect of religiosity and perceived organizational support on life satisfaction through the mediator of meaningful work. However, research conducted by Saliyo et al. (2017) suggested that religiosity can affect the subjective well-being of individuals with the meaning of life as a mediating variable.

Drawing on Frankl's (1984) idea of meaningful work as part of the process of judging life meaning a whole, this study assumes that religiosity can also positively influence life satisfaction through meaningful work as a mediating variable. Zhai et al. (2017) proved that having meaning 
and developing oneself at work can be a link between organizational support and the life satisfaction of employees in China. Therefore, it can be assumed that the perception of organizational support has a positive influence on life satisfaction through employees' meaningful work.

The research question is whether religiosity and perceived organizational support influence the life satisfaction of Christian employees in Indonesia, with meaningful work as a mediating variable. This study proposes new life satisfaction models which are influenced by a personal factor (represented by religiosity), a factor related to work itself (meaningful work), and POS as an organizational factor. Research on life satisfaction among Christian employee is, as far as the author knows, still very rare in Indonesia. This is a research imperative because of its impacts on the productivity and performance of employees and organizations.

Apart from benefits such as salary and career development, Christian employees who work in organizations believe that their jobs are a vocation to serve other people through their profession or expertise. According to Luna-Arocas and Tang (2004), this kind of belief can strengthen their sense of meaningful work. This results in attitudes that do not prioritize remuneration as the main factor in retaining employees. The relationship among the variables is presented in Figure 1.

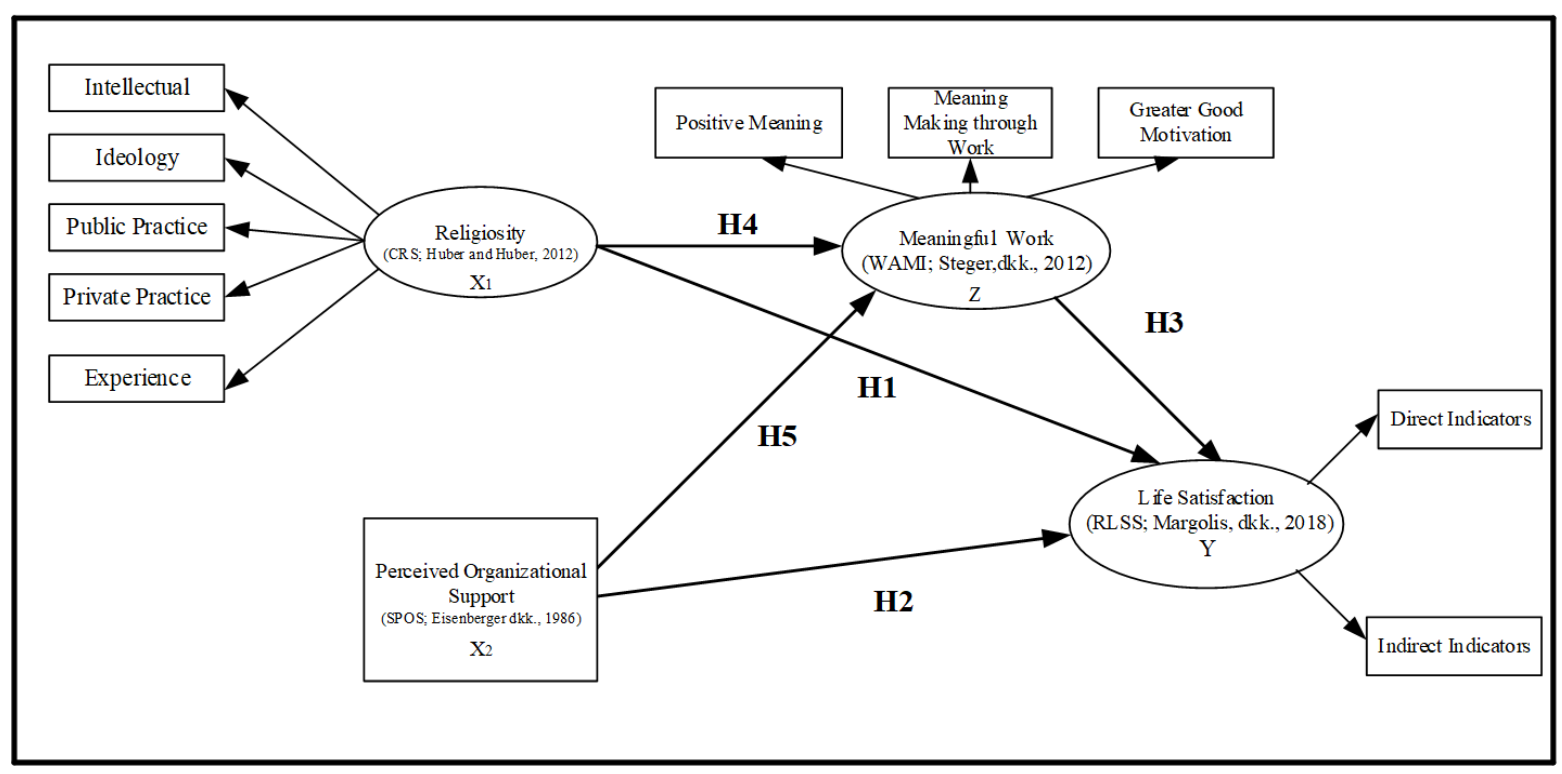

Figure 1. Research Framework

The research hypotheses proposed in this study are that:

$\mathrm{H}_{1}$ : Religiosity has a significant effect on meaningful work. 
$\mathrm{H}_{2}$ : Perceived organizational support has a significant effect on meaningful work.

$\mathrm{H}_{3}$ : Religiosity has a significant effect on life satisfaction.

$\mathrm{H}_{4}$ : Perceived organizational support has a significant effect on life satisfaction.

$\mathrm{H}_{5}$ : Meaningful work has a significant effect on life satisfaction.

$\mathrm{H}_{6}$ : Religiosity affects life satisfaction mediated through meaningful work.

$\mathrm{H}_{7}$ : Perceived organizational support affects life satisfaction mediated through meaningful work.

\section{METHODS}

\section{Participants}

The participants in this study are 263 Christian employees of 118 organizations in Indonesia. These research participants are lecturers, administrative employees, pastor, teachers, doctors, nurses, psychologists, chairpersons of the foundation, HR consultants and psychologists from psychological consulting firms, and employees from state universities, private universities, private banks, hospitals, Christian universities, theological colleges, Christian foundations, Christian schools, and other religious-based organizations in various regions in Indonesia. Before completing the questionnaire, everyone was given a form for informed consent through Google Forms which covered their responses to this research. Detailed demographic data is presented in Table 1.

Table 1.

Demographic Data

\begin{tabular}{clcc}
\hline Variables & \multicolumn{1}{c}{ Categories } & N & $\mathbf{( \% )}$ \\
\hline \multirow{2}{*}{ Sex } & Male & 113 & 43 \\
& Female & 150 & 57 \\
\hline \multirow{3}{*}{ Age } & $20-30$ years old & 37 & 14.1 \\
& $31-40$ years old & 94 & 35.7 \\
& $41-50$ years old & 71 & 27 \\
& $51-60$ years old & 46 & 17.5 \\
& 61-70 years old & 7 & 2.7 \\
& $71-80$ years old & 8 & 3 \\
\hline \multirow{3}{*}{ Education } & Diploma (Ahli Madya/D-III) & 3 & 1.1 \\
& Bachelor (Sarjana S1/D-IV) & 39 & 14.8 \\
& Master (Magister/S2) & 152 & 57.8 \\
& Doctoral (Doktor/S3) & 69 & 26.2 \\
\hline & Lecturer & 192 & 73 \\
& Pastor/priest/preacher & 11 & 4.2 \\
& Psychology practitioner & 14 & 5.3
\end{tabular}




\begin{tabular}{|c|c|c|c|}
\hline Variables & Categories & $\mathbf{N}$ & $(\%)$ \\
\hline & Profesional/private employee & 39 & 14.8 \\
\hline & PNS/ABRI/POLRI & 7 & 2.7 \\
\hline \multirow{6}{*}{ Academic Functional Rank } & Lecturer (Tenaga Pengajar) & 49 & 18.6 \\
\hline & Assistant Professor (Asisten Ahli) & 63 & 24 \\
\hline & Assistant Professor (Lektor) & 54 & 54 \\
\hline & Associate Professor (Lektor Kepala) & 26 & 26 \\
\hline & Full Professor (Guru Besar) & 4 & 1.5 \\
\hline & Other (Lainnya) & 67 & 25.5 \\
\hline \multirow{6}{*}{ Church Ministries } & Church member & 201 & 76.4 \\
\hline & Elders/deacon & 22 & 8.4 \\
\hline & Religious teacher & 3 & 1.1 \\
\hline & Assistant pastor & 11 & 4.2 \\
\hline & Associate pastor & 4 & 1.5 \\
\hline & Full pastor/priest & 22 & 8.4 \\
\hline \multirow{4}{*}{ Married Status } & Divorced & 6 & 2.3 \\
\hline & Widowed & 1 & .4 \\
\hline & Single & 61 & 23.2 \\
\hline & Married & 195 & 74.1 \\
\hline \multirow{4}{*}{ Number of Children } & None or 0 & 93 & 35.4 \\
\hline & $1-2$ persons & 126 & 47.9 \\
\hline & $3-4$ persons & 41 & 15.6 \\
\hline & $5-6$ persons & 3 & 1.1 \\
\hline \multirow{3}{*}{ Couple's Working Status } & Working & 154 & 58.6 \\
\hline & Housewife/househusband & 76 & 28.9 \\
\hline & Other & 33 & 12.5 \\
\hline \multirow{5}{*}{ Length of work } & $1-5$ years & 78 & 29.7 \\
\hline & $6-10$ years & 57 & 21.7 \\
\hline & $10-15$ years & 45 & 17.1 \\
\hline & $15-20$ years & 35 & 13.3 \\
\hline & $>20$ years & 48 & 18.3 \\
\hline \multirow{5}{*}{ Monthly Income } & $<\operatorname{Rp5} .000 .000$ & 61 & 23.2 \\
\hline & Rp5.000.000-Rp10.000.000 & 97 & 38.9 \\
\hline & Rp10.000.000-Rp15.000.000 & 46 & 17.5 \\
\hline & Rp15.000.000-Rp20.000.000 & 26 & 9.9 \\
\hline & $>$ Rp20.000.000 & 33 & 12.5 \\
\hline
\end{tabular}

\section{Design and Analysis Technique}

This research tested the proposed research model and research hypotheses with structural equation modelling (SEM) analysis using PLS software for statistical analysis. According to Ferdinand (2014), SEM PLS is a statistical technique that can help researchers simultaneously test a series of relationships between variables that have a relatively high level of complexity. This relationship is built on one or several dependent variables that arise from one or several independent variables. Each of the research variables can be in the form of factors or constructs built from several sub-variables in the form of dimensions and indicators. Four types of variable data were to 
be measured: life satisfaction, meaningful work, religiosity, and POS. Once the data was obtained, it was analysed using SEM PLS.

\section{Procedure and Measurement}

This research is a quantitative study and used a survey design and questionnaires as the datagathering tool. Purposive sampling was used to identify the research participants. Questionnaires were distributed in two ways, either through Whatsapp groups by sharing the link of the Google Forms version of the questionnaire, or offline by handing the hardcopy to Christian organizations. The data was collected between January and February 2020 after a thorough process of translation and adaptation, following Sperber (2004). All measurement tools used in this study were translated and adapted into an Indonesian-language version (see Table 2).

Life satisfaction as an endogenous variable (Y) was measured using the Riverside Life Satisfaction Scale (RLSS) of Margolis et al. (2018). RLSS consists of two indicators, indirect and direct. This unidimensional scale contains six items with a range of responses that include seven scores ( 1 = "Strongly Disagree"; 7 = "Strongly Agree"). Previous studies have supported the reliability and validity of this measure with a reliability coefficient (mean inter-item correlation $r=$ .69 and internal consistency .93) and the re-test test reliability of .90 (Margolis et al., 2018).

The meaningful work as a mediator variable $(Z)$ was measured through WAMI (The Work and Meaning Inventory) which is based on the meaningful work theory of Steger, Dik, and Duffy (2012); it was translated and adapted for the Indonesian context. This multidimensional tool consists of ten items used to measure three dimensions: positive meaning, meaning-making through work, and good greater motivation. Previous research has supported the fairly high level of reliability and validity of this measuring instrument (loading factor ranges of .60-.92 with item-total correlations ranging of .85-.94) (Steger, Dik, \& Duffy, 2012).

Religiosity as the first endogenous variable $\left(\mathrm{X}_{1}\right)$ was measured by the Centrality of Religiosity Scale (CRS) questionnaire from Huber and Huber (2012). This multidimensional tool consists of 15 items that measure five dimensions of religiosity according to Glock and Stark (1965) and Stark and Glock (1968); it has been used by other researchers examining the concept of religiosity. Previous research has found a good level of reliability and validity for this measure with Cronbach's Alpha internal reliability coefficients ranging from .92-.96 (Huber \& Huber, 2012).

Perceived organizational support (POS) as the second independent variable $\left(\mathrm{X}_{2}\right)$ was measured by SPOS-8 (Survey of Perceived Organizational Support_Eight Items) compiled by 
Eisenberger et al. (1986). This scale consists of eight items that have a scale range of $1-7(1=$ "Strongly Disagree"; 7 = "Strongly Agree") Previous research supports the reliability and validity of this measuring instrument with a Cronbach's Alpha coefficient of .97 and item-total correlations of .42-.83 (Eisenberger et al., 1986; Worley et al., 2009). Following the standard of the International Testing Commission (2017), all instruments in this research have been through a process of forward and back translation for adaptation to the Indonesian context.

Table 2.

Measurement Tools of The Study

\begin{tabular}{cl}
\hline No & \multicolumn{1}{c}{ Riverside Life Satisfaction Scale - RLSS (Indonesian) } \\
\hline 1 & Saya menyukai kehidupan yang saya jalani saat ini. \\
2 & Seandainya saya dapat mengulangi kehidupan saya, saya akan mengubah banyak hal. \\
3 & Saya puas dengan kehidupan saya. \\
4 & Orang-orang di sekitar saya tampaknya mempunyai kehidupan yang lebih baik daripada saya. \\
5 & Saya puas dengan kondisi kehidupan saya saat ini. \\
6 & Saya ingin mengubah jalan hidup saya. \\
\hline
\end{tabular}

No Work and Meaning Inventory - WAMI (Indonesian)

$1 \quad$ Saya telah menemukan karier yang bermakna.

2 Saya memandang pekerjaan saya berkontribusi pada pertumbuhan pribadi saya.

3 Pekerjaan saya benar-benar tidak membuat perubahan pada masyarakat/dunia ini.

4 Saya mengerti bagaimana pekerjaan saya dapat berkontribusi pada makna hidup saya.

5 Saya mengerti apa yang membuat pekerjaan saya bermakna.

6 Saya tahu bahwa pekerjaan saya membuat perubahan yang positif di dalam dunia/masyarakat.

7 Pekerjaan saya menolong saya untuk lebih memahami diri saya.

8 Saya telah menemukan suatu pekerjaan yang memiliki tujuan yang berharga.

9 Pekerjaan saya menolong saya untuk memahami dunia di sekitar saya.

10 Pekerjaan yang saya lakukan memiliki tujuan yang lebih besar.

\begin{tabular}{cl}
\hline No & Centrality of Religiosity Scale - CRS (Indonesian) \\
\hline 1 & Seberapa sering Anda memikirkan tentang masalah-masalah keagamaan? \\
2 & Sejauh mana Anda percaya bahwa Tuhan atau sesuatu yang Ilahi itu nyata? \\
3 & Seberapa sering Anda mengikuti kegiatan ibadah? \\
4 & Seberapa sering Anda berdoa? \\
5 & Seberapa sering Anda mengalami suatu situasi di mana Anda merasa bahwa Tuhan atau sesuatu \\
6 & yang Ilahi turut campur tangan dalam hidup Anda? \\
7 & Sejauh mana Anda tertarik untuk mempelajari lebih dalam tentang topik-topik keagamaan? \\
8 & kebangkitan orang mati, atau reinkarnasi? \\
9 & Seberapa penting bagi Anda untuk mengikuti kegiatan ibadah keagamaan? \\
10 & Seberapa sering Anda mengalami situasi di mana Anda merasa bahwa Tuhan atau sesuatu yang \\
& Ilahi ingin berkomunikasi atau menyingkapkan sesuatu kepada Anda? \\
\hline No & Centrality of Religiosity Scale - CRS (Indonesian) \\
\hline
\end{tabular}

Seberapa sering Anda berusaha mendapatkan informasi tentang tentang topik-topik keagamaan melalui radio, televisi, internet, surat kabar, atau buku? 
12 Menurut pendapat Anda, seberapa besar kemungkinannya bahwa kekuatan Ilahi itu benar-benar ada?

13 Seberapa penting bagi Anda untuk tergabung dalam suatu komunitas keagamaan?

14 Seberapa sering Anda berdoa secara spontan ketika terinspirasi situasi kehidupan sehari-hari?

15 Seberapa sering Anda mengalami situasi di mana anda merasakan kehadiran Tuhan atau sesuatu yang Ilahi?

\begin{tabular}{cl}
\hline No & \multicolumn{1}{c}{ Survey of Perceived Organizational Support (SPOS-8) (Indonesian) } \\
\hline 1 & Organisasi ini menghargai kontribusi saya terhadap kemajuan organisasi. \\
2 & Organisasi ini tidak menghargai kerja ekstra yang saya lakukan. \\
3 & Organisasi ini akan mengabaikan apa pun keluhan saya. \\
4 & Organisasi ini benar-benar peduli pada kesejahteraan saya. \\
5 & Meskipun saya melakukan pekerjaan saya sebaik mungkin, organisasi ini tidak akan \\
6 & Organisatikannya. \\
7 & Organisasi ini meduli terhadap kepuasan kerja saya. \\
8 & Organisasi ini membanggakan pencapaian kerja saya. \\
\hline
\end{tabular}

\section{RESULTS}

Before SEM analysis, we categorized the total scores of the respondents into five categories (very high, high, moderate, low, and very low) as a formula of categorization norms proposed by Azwar (2012). The categorization of the scores of each variable can be seen in Table 3 . This stage then was followed by partial least square (PLS) regression consisting of two main stages: evaluations of the outer model and the inner model.

Table 3.

Norms of Categorization of Research Variable Total Scores

\begin{tabular}{lcccccccc}
\hline \multirow{2}{*}{ Level } & \multicolumn{2}{c}{ Life Satisfaction } & \multicolumn{2}{c}{ Meaningful Work } & \multicolumn{2}{c}{ Religiosity } & \multicolumn{2}{c}{ POS } \\
\cline { 2 - 9 } & $\boldsymbol{F}$ & $\mathbf{( \% )}$ & $\boldsymbol{F}$ & $\mathbf{( \% )}$ & $\boldsymbol{F}$ & $\mathbf{( \% )}$ & $\boldsymbol{F}$ & $\mathbf{( \% )}$ \\
\hline Very High & 88 & 33.46 & 217 & 82.51 & 181 & 68.82 & 86 & 32.70 \\
High & 101 & 38.40 & 38 & 14.45 & 72 & 27.38 & 73 & 27.76 \\
Moderate & 61 & 23.19 & 7 & 2.66 & 10 & 3.80 & 85 & 32.32 \\
Low & 10 & 3.80 & 1 & .38 & 0 & .00 & 14 & 5.32 \\
Very Low & 3 & 1.14 & 0 & .00 & 0 & .00 & 5 & 1.90 \\
\hline Total & 263 & 100 & 263 & 100 & 263 & 100 & 263 & 100 \\
\hline
\end{tabular}

\section{Outer Model Evaluation}

Outer model evaluation on PLS analysis was conducted to test the construct validity and reliability used in the structural model of the study. The validity test consists of convergent and discriminant validity, while Cronbach's Alpha and composite reliability are used to test construct reliability. The estimation results with PLS on the outer model are presented in Figure 2. 


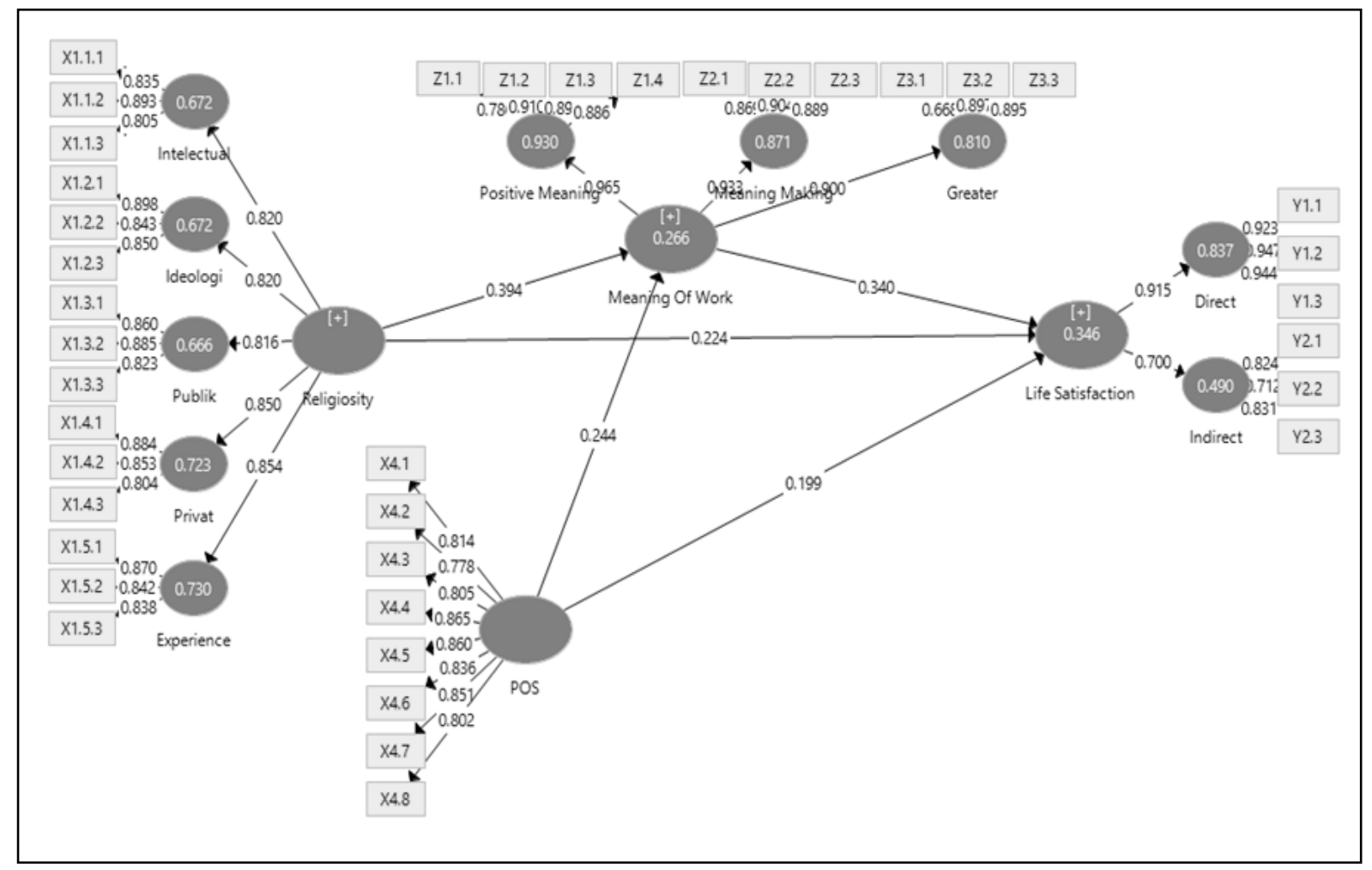

Figure 2. Estimation of PLS (Outer Model)

\section{Convergent Validity}

The results of convergent validity evaluation by using outer loading and average variance extracted (AVE) values are shown in Table 4. 
Table 4.

Outer Loading and AVE (Convergent Validity) of the Studied Variables

\begin{tabular}{|c|c|c|c|c|c|c|c|}
\hline Variable & Dimension & Item & $\begin{array}{c}\text { Outer } \\
\text { Loading }\end{array}$ & $\begin{array}{c}T \\
\text { Statistics } \\
\end{array}$ & $\begin{array}{c}\text { AVE } \\
\text { Variable } \\
\end{array}$ & $\begin{array}{c}\text { AVE } \\
\text { Dimension }\end{array}$ & Status \\
\hline \multirow{15}{*}{ Religiosity } & \multirow[t]{3}{*}{ Intellectual } & X1.1.1 & .835 & 40.626 & \multirow[t]{3}{*}{.503} & \multirow[t]{3}{*}{.714} & \multirow{15}{*}{ Valid } \\
\hline & & $\mathrm{X} 1.1 .2$ & .893 & 73.826 & & & \\
\hline & & X1.1.3 & .805 & 31.552 & & & \\
\hline & \multirow[t]{3}{*}{ Ideology } & $\mathrm{X} 1.2 .1$ & .898 & 56.398 & & \multirow[t]{3}{*}{.747} & \\
\hline & & $\mathrm{X} 1.2 .2$ & .843 & 37.248 & & & \\
\hline & & $\mathrm{X} 1.2 .3$ & .850 & 31.895 & & & \\
\hline & \multirow[t]{3}{*}{ Public } & $\mathrm{X} 1.3 .1$ & .860 & 46.533 & & \multirow[t]{3}{*}{.733} & \\
\hline & & $\mathrm{X} 1.3 .2$ & .885 & 59.581 & & & \\
\hline & & $\mathrm{X} 1.3 .3$ & .823 & 36.665 & & & \\
\hline & \multirow[t]{3}{*}{ Privat } & $\mathrm{X} 1.4 .1$ & .884 & 62.292 & & \multirow[t]{3}{*}{.719} & \\
\hline & & $\mathrm{X} 1.4 .2$ & .853 & 45.419 & & & \\
\hline & & $\mathrm{X} 1.4 .3$ & .804 & 34.880 & & & \\
\hline & \multirow[t]{3}{*}{ Experience } & $\mathrm{X} 1.5 .1$ & .870 & 53.521 & & \multirow[t]{3}{*}{.723} & \\
\hline & & $\mathrm{X} 1.5 .2$ & .842 & 43.967 & & & \\
\hline & & $\mathrm{X} 1.5 .3$ & .838 & 39.995 & & & \\
\hline \multirow[t]{8}{*}{ POS } & & $\mathrm{X} 4.1$ & .814 & 31.226 & \multirow[t]{8}{*}{.684} & & \multirow[t]{8}{*}{ Valid } \\
\hline & & $\mathrm{X} 4.2$ & .778 & 21.865 & & & \\
\hline & & $\mathrm{X} 4.3$ & .805 & 23.946 & & & \\
\hline & & X4.4 & .865 & 52.759 & & & \\
\hline & & $X 4.5$ & .860 & 43.361 & & & \\
\hline & & X4.6 & .836 & 34.890 & & & \\
\hline & & $\mathrm{X} 4.7$ & .850 & 36.615 & & & \\
\hline & & $\mathrm{X} 4.8$ & .802 & 27.508 & & & \\
\hline \multirow{10}{*}{$\begin{array}{l}\text { Meaningful } \\
\text { Work }\end{array}$} & \multirow[t]{4}{*}{ PM } & Z1.1 & .786 & 24.391 & \multirow[t]{10}{*}{.653} & \multirow[t]{4}{*}{.759} & \multirow[t]{10}{*}{ Valid } \\
\hline & & $\mathrm{Z} 1.2$ & .910 & 65.677 & & & \\
\hline & & $\mathrm{Z} 1.3$ & .899 & 53.306 & & & \\
\hline & & Z1.4 & .886 & 55.050 & & & \\
\hline & \multirow[t]{3}{*}{ MMW } & $\mathrm{Z} 2.1$ & .869 & 43.540 & & \multirow[t]{3}{*}{.787} & \\
\hline & & $\mathrm{Z} 2.2$ & .904 & 46.596 & & & \\
\hline & & $\mathrm{Z} 2.3$ & .889 & 51.408 & & & \\
\hline & \multirow{3}{*}{ GM } & $\mathrm{Z} 3.1$ & .668 & 10.355 & & \multirow{3}{*}{.684} & \\
\hline & & $\mathrm{Z} 3.2$ & .897 & 63.993 & & & \\
\hline & & $\mathrm{Z} 3.3$ & .895 & 67.068 & & & \\
\hline $\begin{array}{l}\text { Life } \\
\text { Satisfaction }\end{array}$ & $\begin{array}{c}\text { Direct } \\
\text { Indicators }\end{array}$ & Y1.1 & .923 & 60.368 & .521 & .880 & Valid \\
\hline & & Y1.2 & .947 & 83.845 & & & \\
\hline & & Y1.3 & .944 & 84.423 & & & \\
\hline & $\begin{array}{l}\text { Indirect } \\
\text { Indicators }\end{array}$ & Y 2.1 & .824 & 30.620 & & .626 & \\
\hline & & Y 2.2 & .712 & 17.169 & & & \\
\hline & & Y2.3 & .831 & 36.906 & & & \\
\hline
\end{tabular}


Table 4 shows that all outer loadings used in each dimension of the variable are greater than the provision of .5. Meanwhile, the AVE value of all variables and dimensions are greater than .5, indicating that the items used in the structural model have good validity.

\section{Discriminant Validity}

Discriminant validity testing was done by looking at the value of cross-loading and FornellLarcker criterion. The results of the discriminant validity test in Table 5 shows that the largest outer loading value in the measurement of each latent variable is in the latent variable which is measured by the previously constructed indicator items. Therefore, discriminant validity in the structural model has been fulfilled.

Meanwhile, the other discriminant validity tests with the Fornell-Larcker criterion are presented in Table 6; note that the AVE roots contained in the diagonal rows of each variable have a greater value than the correlation values associated with these variables. Thus it can be concluded that testing through the Fornell-Larcker coefficient below, the discriminant validity of this structural model has been fulfilled.

\section{Composite Reliability}

Internal consistency testing was conducted through reliability testing on the structural model variables using Smart PLS 3.2.7, consisting of composite reliability and Cronbach's Alpha values as demonstrated in Table 7. The composite reliability value of each variable is greater than .7 and Cronbach's Alpha value is also greater than .6. Thus, the aspects of reliability and consistency of the measurement variables in the structural model have been fulfilled. 
Table 5.

Cross Loading Item Factors

\begin{tabular}{|c|c|c|c|c|c|c|c|c|c|c|c|}
\hline & X1.1 & X1.2 & $\mathrm{X} 1.3$ & X1.4 & $\mathrm{X} 1.5$ & $\mathrm{X} 4$ & Z1 & $\mathbf{Z 2}$ & $\mathbf{Z 3}$ & Y1 & Y2 \\
\hline $\mathrm{X} 1.1 .1$ & .84 & .44 & .57 & .52 & .44 & .17 & .36 & .33 & .36 & .31 & .11 \\
\hline $\mathrm{X} 1.1 .2$ & .89 & .51 & .61 & .53 & .55 & .19 & .34 & .35 & .30 & .37 & .05 \\
\hline $\mathrm{X} 1.1 .3$ & .81 & .39 & .56 & .53 & .51 & .17 & .26 & .24 & .20 & .30 & .07 \\
\hline $\mathrm{X} 1.2 .1$ & .47 & .90 & .51 & .57 & .61 & .21 & .34 & .36 & .34 & .43 & .16 \\
\hline $\mathrm{X} 1.2 .2$ & .49 & .84 & .54 & .49 & .53 & .26 & .31 & .30 & .27 & .31 & .17 \\
\hline $\mathrm{X} 1.2 .3$ & .42 & .85 & .42 & .50 & .66 & .21 & .38 & .41 & .42 & .37 & .12 \\
\hline X1.3.1 & .54 & .50 & .86 & .52 & .44 & .22 & .34 & .31 & .29 & .35 & .16 \\
\hline $\mathrm{X} 1.3 .2$ & .58 & .51 & .89 & .56 & .49 & .22 & .27 & .27 & .26 & .34 & .11 \\
\hline $\mathrm{X} 1.3 .3$ & .64 & .44 & .82 & .47 & .48 & .19 & .33 & .30 & .27 & .35 & .10 \\
\hline X1.4.1 & .54 & .50 & .55 & .88 & .58 & .15 & .31 & .32 & .23 & .33 & .11 \\
\hline $\mathrm{X} 1.4 .2$ & .49 & .60 & .53 & .85 & .61 & .16 & .26 & .29 & .23 & .29 & .11 \\
\hline $\mathrm{X} 1.4 .3$ & .54 & .44 & .46 & .80 & .61 & .15 & .26 & .28 & .26 & .30 & .05 \\
\hline X1.5.1 & .46 & .71 & .44 & .61 & .87 & .24 & .35 & .34 & .31 & .40 & .13 \\
\hline $\mathrm{X} 1.5 .2$ & .54 & .52 & .50 & .61 & .84 & .14 & .31 & .29 & .28 & .35 & .12 \\
\hline $\mathrm{X} 1.5 .3$ & .51 & .54 & .47 & .58 & .84 & .13 & .27 & .28 & .29 & .33 & .06 \\
\hline X4.1 & .20 & .24 & .23 & .17 & .20 & .81 & .36 & .29 & .29 & .33 & .17 \\
\hline $\mathrm{X} 4.2$ & .12 & .23 & .20 & .15 & .11 & .78 & .21 & .17 & .13 & .24 & .24 \\
\hline X4.3 & .14 & .23 & .22 & .13 & .16 & .81 & .26 & .20 & .21 & .27 & .21 \\
\hline X4.4 & .22 & .21 & .24 & .18 & .21 & .87 & .36 & .29 & .27 & .35 & .21 \\
\hline X4.5 & .17 & .27 & .21 & .14 & .18 & .86 & .27 & .23 & .21 & .27 & .26 \\
\hline X4.6 & .20 & .15 & .17 & .14 & .12 & .84 & .33 & .31 & .29 & .28 & .16 \\
\hline X4.7 & .14 & .17 & .17 & .13 & .16 & .85 & .25 & .24 & .20 & .24 & .26 \\
\hline $\mathrm{X} 4.8$ & .18 & .24 & .19 & .17 & .17 & .80 & .33 & .26 & .29 & .31 & .19 \\
\hline Z1.1 & .32 & .33 & .33 & .27 & .31 & .36 & .79 & .63 & .56 & .54 & .31 \\
\hline Z1.2 & .33 & .35 & .32 & .29 & .33 & .33 & .91 & .79 & .73 & .44 & .24 \\
\hline Z1.3 & .32 & .35 & .30 & .29 & .33 & .32 & .90 & .76 & .75 & .40 & .22 \\
\hline Z1.4 & .35 & .36 & .32 & .28 & .31 & .28 & .89 & .78 & .77 & .46 & .28 \\
\hline Z2.1 & .35 & .33 & .27 & .28 & .31 & .29 & .79 & .87 & .65 & .49 & .25 \\
\hline $\mathrm{Z} 2.2$ & .30 & .37 & .29 & .31 & .30 & .24 & .72 & .90 & .66 & .37 & .18 \\
\hline Z2.3 & .32 & .40 & .35 & .33 & .34 & .28 & .77 & .89 & .71 & .39 & .30 \\
\hline Z3.1 & .17 & .18 & .13 & .17 & .16 & .28 & .43 & .39 & .67 & .17 & .20 \\
\hline Z3.2 & .34 & .39 & .34 & .29 & .35 & .20 & .74 & .69 & .90 & .38 & .17 \\
\hline Z3.3 & .30 & .37 & .28 & .23 & .31 & .27 & .78 & .74 & .90 & .38 & .21 \\
\hline Y1.1 & .34 & .39 & .38 & .35 & .39 & .33 & .47 & .43 & .35 & .92 & .29 \\
\hline Y1.2 & .37 & .40 & .38 & .31 & .39 & .35 & .50 & .45 & .38 & .95 & .33 \\
\hline Y1.3 & .37 & .40 & .39 & .34 & .41 & .31 & .51 & .45 & .37 & .94 & .37 \\
\hline Y 2.1 & -.01 & .07 & .06 & .00 & .02 & .15 & .20 & .19 & .14 & .25 & .82 \\
\hline Y 2.2 & .14 & .20 & .17 & .17 & .20 & .13 & .24 & .23 & .21 & .25 & .71 \\
\hline Y2.3 & .08 & .14 & .12 & .08 & .08 & .30 & .27 & .23 & .20 & .33 & .83 \\
\hline
\end{tabular}


Table 6.

Fornell-Larcker Latent Variables

\begin{tabular}{lcccc}
\hline & Religiosity & POS & Meaningful Work & Life Satisfaction \\
\hline Religiosity & $\mathbf{. 7 0 9}$ & & & \\
POS & .265 & $\mathbf{. 8 2 7}$ & & \\
Meaningful Work & .459 & .348 & $\mathbf{. 8 0 8}$ & $\mathbf{. 7 2 2}$ \\
Life Satisfaction & .435 & .377 & .512 & \\
\hline
\end{tabular}

Table 7.

Composite Reliability Laten Variables

\begin{tabular}{lccc}
\hline & Composite Reliability & Cronbach's Alpha & Description \\
\hline Religiosity & .938 & .929 & Reliable \\
POS & .945 & .934 & Reliable \\
Meaningful Work & .949 & .938 & Reliable \\
Life Satisfaction & .862 & .804 & Reliable \\
\hline
\end{tabular}

\section{Inner Model Evaluation}

The inner model was evaluated to determine the effect between the research variables contained in the structural model. Evaluation of the inner model consists of the coefficient of determination $\left(R^{2}\right)$, predictive relevance $\left(Q^{2}\right)$, and $f^{2}$ value. The results of the inner model estimation in full can be seen in Figure 3.

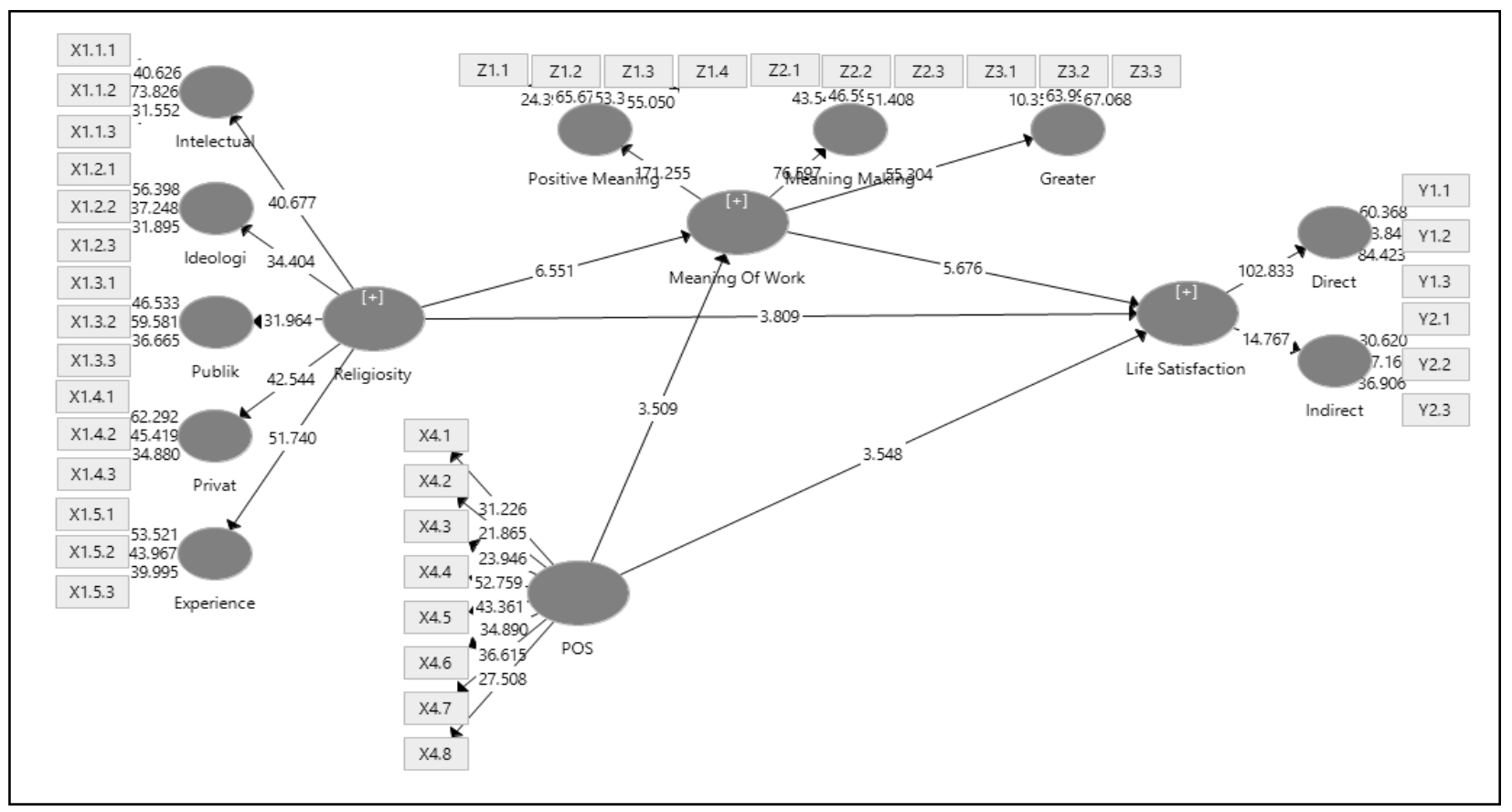

Figure 3. Estimation of PLS (Inner Model) 


\section{R-Square Value}

R-Squared value was performed to test the diversity of changes in the independent variables on the dependent variable. The results of the estimation of the R-Squared "meaningful work" variable shows a value of .266, meaning that the diversity of the perception of meaningful work can be explained by the perception of religiosity and POS by $26.6 \%$, while the remaining $73.4 \%$ is explained by other factors not used in the model. Meanwhile, the R-Squared value of the variable "life satisfaction" was .346 , meaning that the diversity of the perception of life satisfaction can be explained by the perception of religiosity, POS, and meaningful work by $34.6 \%$ while the remaining $65.4 \%$ is explained by other factors not used in the model. An evaluation of R-squared value was used to measure the level of variation in changes caused by exogenous variables to endogenous variables, and whether exogenous variables have a substantive influence on endogenous variables.

In the PLS analysis, the conceptual model was evaluated by calculating goodness of fit (GoF). The GoF measurement was used to calculate the multiplication between the average value of communalities and the average R-Square value. GoF values range from 0 to 1 . Table 8 below shows a GoF score of $d=\sqrt{ } 30.306 \times .587=.424$. The calculation resulting from the GoF value in this research is .424 , indicating that the suitability of the conceptual model developed is already good (scored above .36).

Table 8.

R-Square Structural Model

\begin{tabular}{lccc}
\hline \multicolumn{1}{c}{ Variable } & R-Square & Description & Communalities \\
\hline Meaningful Work & .266 & Moderate & .653 \\
Life Satisfaction & .346 & Moderate & .521 \\
\hline Mean & .306 & & .587 \\
\hline
\end{tabular}

\section{$Q^{2}$ Coefficient}

The $Q^{2}$ coefficient was used to determine the predictive capacity of the structured model. $\mathrm{Q}^{2}$ values are calculated using the formula:

$$
\begin{aligned}
\mathrm{Q}^{2} & =1-\left[\left(1-\mathrm{R}_{1}^{2}\right) \times\left(1-\mathrm{R}_{2}^{2}\right)\right] \\
& =1-[(1-0.266) \times(1-0.346)] \\
& =1-0.480 \\
& =0.520
\end{aligned}
$$


The division of categories in $Q^{2}$ is also threefold: .02 is a weak influence; .15 is a moderate influence; .35 is a strong influence (Mustafa \& Wijaya, 2012; Sarwono \& Narimawati, 2015). The results of the calculation of the $Q^{2}$ value are known to be .520 . Based on these results, it can be concluded that the structural model that has been prepared is able to make good predictions or has predictive relevance.

\section{$f^{2}$ Value}

The $f^{2}$ value was conducted to determine the predictor of a latent variable used in a structural model. Table 9 displayed the results of the $f^{2}$ value in the structural model.

Table 9.

f2 Value Path of Structural Model

\begin{tabular}{lll}
\hline \multicolumn{1}{c}{ Pathway Analysis } & $\boldsymbol{f}^{2}$ & Effect Size \\
\hline Religiosity $\rightarrow$ Meaningful Work & .197 & Moderate \\
POS $\rightarrow$ Meaningful Work & .075 & Moderate \\
Religiosity $\rightarrow$ Life Satisfaction & .060 & Moderate \\
POS $\rightarrow$ Life Satisfaction & .052 & Moderate \\
Meaningful Work $\rightarrow$ Life Satisfaction & .130 & Moderate \\
\hline
\end{tabular}

As with $Q^{2}$ the division of categories in $f^{2}$ is also threefold: .02 is a weak influence; .15 is a moderate influence; .35 is a strong influence (Mustafa \& Wijaya, 2012; Sarwono \& Narimawati, 2015). The results conclude that all variables have moderate effect sizes in the structural model.

\section{Hypothesis Testing}

The correlation matrix between the indicators in this study is presented in Table 10. The inner weights value generated in the estimated bootstrapping PLS analysis demonstrates the effect of a variable on other variables (Otok et al., 2017). The evaluation of inner weights in this research was used to observe the direct and indirect effects and to test the hypotheses between variables. The inner weight results with bootstrapping are shown in Table 11. 
Table 10.

Correlation Matrix between Research Variable Dimensions

\begin{tabular}{|c|c|c|c|c|c|c|c|c|c|c|c|c|c|c|}
\hline & 1 & 2 & 3 & 4 & 5 & 6 & 7 & 8 & 9 & 10 & 11 & 12 & 13 & 14 \\
\hline Direct & - & & & & & & & & & & & & & \\
\hline Experience & $.423^{* *}$ & - & & & & & & & & & & & & \\
\hline Greater & $.391^{* *}$ & $.345^{* *}$ & - & & & & & & & & & & & \\
\hline Ideology & $.426^{* *}$ & $.693^{* *}$ & $.396^{* *}$ & - & & & & & & & & & & \\
\hline Indirect & $.352^{* *}$ & .121 & $.231^{* *}$ & $.174^{*}$ & - & & & & & & & & & \\
\hline Intellectual & $.384^{* *}$ & $.592^{* *}$ & $.338^{* *}$ & $.532^{* *}$ & .085 & - & & & & & & & & \\
\hline Life satisfaction & $.915^{* *}$ & $.375^{* *}$ & $.398^{* *}$ & $.401^{* *}$ & $.700^{* *}$ & $.331^{* *}$ & - & & & & & & & \\
\hline Meaning making & $.472^{* *}$ & $.359^{* *}$ & $.758^{* *}$ & $.414^{* *}$ & $.276^{* *}$ & $.362^{* *}$ & $.480^{* *}$ & - & & & & & & \\
\hline Meaning of work & $.505^{* *}$ & $.383^{* *}$ & $.900^{* *}$ & $.429^{* *}$ & $.293^{* *}$ & $.387^{* *}$ & $.512^{* *}$ & $.933^{* *}$ & - & & & & & \\
\hline POS & $.351^{* *}$ & $.201^{*}$ & $.292^{* *}$ & $.261^{* *}$ & $.252^{* *}$ & $.210^{*}$ & $.377^{* *}$ & $.305^{* *}$ & $.348^{* *}$ & - & & & & \\
\hline Positive meaning & $.525^{* *}$ & $.368^{* *}$ & $.811^{* *}$ & $.397^{* *}$ & $.300^{* *}$ & $.378^{* *}$ & $.530^{* *}$ & $.855^{* *}$ & $.965^{* *}$ & $.364^{* *}$ & - & & & \\
\hline Private & $.357^{* *}$ & $.707^{* *}$ & $.283^{* *}$ & $.605^{* *}$ & .103 & $.618^{* *}$ & $.318^{* *}$ & $.345^{* *}$ & $.341^{* *}$ & $.182^{*}$ & $.322^{* *}$ & - & & \\
\hline Public & $.408^{* *}$ & $.551^{* *}$ & $.317^{* *}$ & $.566^{* *}$ & .144 & $.682^{* *}$ & $.373^{* *}$ & $.342^{* *}$ & $.367^{* *}$ & $.248^{* *}$ & $.362^{* *}$ & $.605^{* *}$ & - & \\
\hline Religiosity & $.481^{* *}$ & $.854^{* *}$ & $.405^{* *}$ & $.820^{* *}$ & .151 & $.820^{* *}$ & $.433^{* *}$ & $.439^{* *}$ & $.459^{* *}$ & $.265^{* *}$ & $.440^{* *}$ & $.850^{* *}$ & $.816^{* *}$ & - \\
\hline
\end{tabular}

Note: ${ }^{*}=$ Significant at .05 level; ${ }^{* *}=$ Significant at .001 level

Table 11.

Direct, Indirect, and Total Effect of Structural Model

\begin{tabular}{lcccccc}
\hline \multirow{2}{*}{ Pathway } & \multicolumn{2}{c}{ Direct Effect } & \multicolumn{2}{c}{ Indirect Effect } & \multicolumn{2}{c}{ Total Effect } \\
\cline { 2 - 7 } & $\begin{array}{c}\text { Original } \\
\text { Sample }\end{array}$ & \multicolumn{1}{c}{$\boldsymbol{t}$} & $\begin{array}{c}\text { Original } \\
\text { Sample }\end{array}$ & $\boldsymbol{t}$ & $\begin{array}{c}\text { Original } \\
\text { Sample }\end{array}$ & $\boldsymbol{t}$ \\
\hline $\begin{array}{l}\text { Religiosity } \rightarrow \text { Meaningful } \\
\text { Work }\end{array}$ & .394 & $6.551^{* *}$ & & & .394 & $6.551^{* *}$ \\
POS $\rightarrow$ Meaningful Work & .244 & $3.509^{* *}$ & & & .244 & $3.509^{* *}$ \\
\hline $\begin{array}{l}\text { Religiosity } \rightarrow \quad \text { Life } \\
\text { Satisfaction }\end{array}$ & .224 & $3.809^{* *}$ & .134 & $3.949^{* *}$ & .358 & $6.305^{* *}$ \\
$\begin{array}{l}\text { POS } \rightarrow \text { Life Satisfaction } \\
\text { Meaningful Work } \rightarrow \text { Life }\end{array}$ & .199 & $3.548^{* *}$ & .083 & $2.991^{*}$ & .282 & $4.548^{* *}$ \\
Satisfaction & .340 & $5.676^{* *}$ & & & .340 & $5.676^{* *}$ \\
\hline Note: ${ }^{*}=$ Significant at .05 level; ${ }^{* *}=$ Significant at .001 level & & & &
\end{tabular}

As demonstrated in Table 11, the influence of the pathways that occur are all positive and meaningful, both directly and indirectly. However, the direct effect of $\mathrm{X}_{1}$ on $\mathrm{Y}$ and the direct effect of $\mathrm{X}_{2}$ on $\mathrm{Y}$ is still greater than the influence of $\mathrm{X}_{1}$ or $\mathrm{X}_{2}$ on $\mathrm{Y}$ through the mediating variables of "meaningful work". Therefore, within these pathways, meaningful work can be a partial mediating variable of religiosity, as well as POS on the life satisfaction of Christian employees in several organizations in Indonesia. Based on the above analysis, it can be concluded that all alternative research hypotheses (Hypothesis 1-7) in this study are accepted. 


\section{DISCUSSION}

This research model aims to determine the effect of religiosity and POS on the life satisfaction of Christian employees, mediated through the variable of meaningful work. Respectively, the direct effect relationship between religiosity and meaningful work is found to be positive and significant. This result supports previous research that found that the religiosity factor has an impact on business ethics and the ethical behaviour of entrepreneurs in business (Fauzan, 2013), and that religiosity also can affect how people think about their jobs and working life (Davidson \& Caddell, 1994). Thus, religiosity affects the dimension of meaningful work.

According to the statistical analysis, this study found that POS has a significant positive influence on meaningful work. This result is supported by previous research conducted by Claudia (2018), which found that lecturers who feel supported by their organization will gain deeper meaning when doing their job. This will indirectly increase their commitment to higher education institutions and to their work. Akgunduz et al. (2018) found that meaningful work can be a mediating variable between perceptions of organizational support and job satisfaction, and employee's creativity and proactive personality, respectively.

The direct effect of religiosity on the life satisfaction of Christian employees is positive and significant. These results support the theory of Koenig (1998) and Koenig and Larson (2001) which imply that the level of religiosity has a positive influence on life satisfaction. Previous studies in Indonesia have found that religiosity had a very significant relationship with the well-being of the employees of UMM Malang (Karim, 2018) and of TNI soldiers in Jakarta (Hamidah \& Gamal, 2019). The significant positive direct effect of POS on the life satisfaction of participants is demonstrated with the inner weight score. This result supports previous research conducted by Valentine et al. (2006) and Meyers et al. (2018) which established that POS has a positive relationship with employee life satisfaction. Roemer and Harris (2018) also show that POS can affect employee well-being, through psychological capital, in South Africa.

The direct effect of meaningful work on the life satisfaction of Christian employees is positive and significant. The findings reveal a direct link between meaningful work and individual life satisfaction. In a similar study, Allan et al. (2016) stated that meaningful work has a positive influence on life satisfaction, mental health, and human life and welfare in general. The results of this study accord with another study that found a correlation between meaningful work and the life satisfaction of elementary school teachers in the USA by Shyim and Korb (2016). Van Wingerden 
and Van der Stoep (2017) in the Netherlands also showed that meaningful work can correlate with the general well-being of company employees.

The research model aims to determine the effect of religiosity and POS on the life satisfaction of Christian employees through meaningful work as a mediating variable. The study found that the construct of meaningful work can be partial mediator of the relationship between religiosity and POS with life satisfaction, in which religiosity has a positively significant stronger indirect effect while POS has a positively significant but weaker indirect effect. The selection of meaningful work as a mediator was based on the statement of Frankl (1984) and also research by Erdogan et al. (2012). Previously, meaningful work as a mediator had been scarcely used to examine the relationship between religiosity, the meaning of life, and life satisfaction (Chamberlain \& Zika, 1988). Other Turkish research by Akgunduz et al. (2018) and a Malaysian study by Ahmed et al. (2019) respectively implied that meaningful work can be used as a mediating variable, though its functions are only partial.

It should be noted one of the limitations in this study is the research data that are not normally distributed. Normally, research of this kind should use SEM AMOS analysis; however, the non normal distribution of the data made the researcher used SEM PLS instead (Achjari, 2004). Further research could use a bigger pool of respondents to get more significant detail and to minimize the chance of data abnormality. Another limitation of this research is the use of online questionnaires where researchers cannot observe the actual situation of the respondents, who are geographically dispersed. Furthermore, this research does not use probability sampling in data collection, so the findings do not describe the general population of Christian employees in Indonesia.

\section{CONCLUSION AND RECOMMENDATIONS}

\section{Conclusion}

The aim of this research is to investigate whether religiosity and POS influence the satisfaction of Christian employees in Indonesia through meaningful work as a mediating variable. Its findings show that the framework model is accepted, and that further study can use it as solid base for research regarding the relationship between meaningful work and life satisfaction. Based on these results and discussion, it is determined that the perceived model is considered fit, with the inclusion of "meaningful work" as a partially mediating variable. "Meaningful work" is presented 
as an essential variable in the development of life satisfaction for Christian employees. It should be noted that the designed construct of this study suggests that meaningful work should function as a full mediator between religiosity, POS, and life satisfaction; therefore, without a deeper understanding of meaningful work, there would be no effect of religiosity or POS on life satisfaction. However, the findings of this study suggest that meaningful work only functions as a partial mediator, not a full mediator as expected. There is thus already a direct effect of either religiosity or POS on life satisfaction.

\section{Theoretical Recommendations}

An implication of this study is that the function of meaningful work as a mediating variable must be strengthened. It is necessary to re-examine the concept of religiosity, meaningful work, organizational support, and job satisfaction for employees in Indonesia; this may differ from subjects in Western societies. The results of this study are also unique considering that all of the research respondents have the same characteristics, as Christian employees who work in various organizations in Indonesia.

Meanwhile, the factors that influence life satisfaction need to be added to other related factors such as self-efficacy and social support, which have previously been shown to have a relationship with life satisfaction. Further research is needed to confirm the data that has been obtained in this study by interviewing several respondents to find out more about their level of life satisfaction. Finally, considering that this research was conducted among Christian workers, further research can explore the link between the results of this study and the concept of "the Protestant work ethic" to better understand the phenomena among respondents.

\section{Practical Recommendations}

To enhance the understanding of Christian employees regarding their position in a pluralist and heterogeneous Indonesian, these workers should be better supported by their peers to foster a well-rounded community. Frequent recognition can encourage individuals to do more good work, while fostering a community gives people an opportunity to share who they are with their colleagues and to create the kind of place in which they would want to work. Support from the organization for the life satisfaction of its employees also needs to be improved in the future, considering that, according to the results of this study, there are still those who feel that support from their organization is only moderate or low. 


\section{FUNDING}

The authors received no specific funding for this work.

\section{COMPLIANCE WITH ETHICAL STANDARD}

\section{Ethical Statement}

All procedures performed in this study were in accordance with the 1964 Helsinki Declaration and its amendments or with comparable ethical standards. Informed consent has been obtained from all participants in this study.

\section{Conflict of Interest}

The authors declare that they have no conflict of interest.

\section{Data Availability}

The datasets used in this study are available from the corresponding author through email.

\section{REFERENCES}

Achjari, D. (2004). Partial least squares: Another method of structural equation modelling analysis. Journal of Indonesian Economy and Business, 19(3), 238-248.

Ahmed, U., Majid, A., Al-Aali, L., \& Mozammel, S. (2019). Can meaningful work really moderate the relationship between supervisor support, co-worker support and work engagement. Management Science Letters, 9(2), 229-242. https://doi.org/10.5267/j.msl.2018.11.016

Akgunduz, Y., Alkan, C., \& Gök, Ö. A. (2018). Perceived organizational support, employee creativity and proactive personality: The mediating effect of meaning of work. Journal of Hospitality and Tourism Management, 34, 105-114. https://doi.org/10.1016/j.jhtm.2018.01.004

Allan, B. A., Dexter, C., Kinsey, R., \& Parker, S. (2016). Meaningful work and mental health: Job satisfaction as a moderator. Journal of Mental Health, 27(1), 38-44. https://doi.org/10.1080/09638237.2016.1244718

Argyle, M. (2001). The psychology of happiness (2nd ed.). Routledge.

Astin, A. W. (2004). Why spirituality deserves a central place in liberal education. Liberal Education, 90(2), 34-41. 
Azwar, S. (2012). Penyusunan skala psikologi. Pustaka Pelajar.

Bachtiar, D., Sudibjo, N., \& Bernarto, I. (2018). The effects of transformational leadership, perceived organizational support on job and life satisfaction of preschool teachers. International Information Institute (Tokyo). Information, 21(4), 1301-1320. https://search.proquest.com/openview/ba292bba25919fe96aa3a3ff836d3213/1?pqorigsite $=$ gscholar \&cbl $=936334$

Chamberlain, K., \& Zika, S. (1988). Religiosity, life meaning and wellbeing: Some relationships in a sample of women. Journal for the Scientific Study of Religion, 27(3), 411-420. https://doi.org/10.2307/1387379

Claudia, M. (2018). The influence of perceived organizational support, job satisfaction and organizational commitment toward organizational citizenship behavior (A study of the permanent lecturers at University of Lambung Mangkurat, Banjarmasin). Journal of Indonesian Economy and Business, 33(1), 23-45. https://doi.org/10.22146/jieb.17761

Compton W. C. (2005). An introduction to positive psychology. Cengage Learning.

Davidson, J. C., \& Caddell, D. P. (1994). Religion and the meaning of work. Journal for the Scientific Study of Religion, 33(2), 135-147. https://doi.org/10.2307/1386600

Diener, E., Oishi, S., \& Lucas, R. E. (2003). Personality culture, and subjective well-being: Emotional and cognitive evaluation of life. Annual Review of Psychology, 54, 403-425.

Eisenberger, R., Huntington, R., Hutchison, S., \& Sowa, D. (1986). Perceived organizational

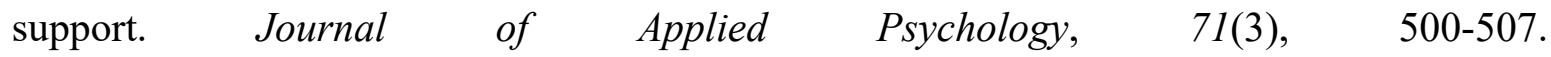
https://psycnet.apa.org/doi/10.1037/0021-9010.71.3.500.

Erdogan, B., Bauer, T. N., Truxillo, D. M., \& Mansfield, L. R. (2012). Whistle while you work: A review of the life satisfaction literature. Journal of Management, 38(4), 1038-1083. https://doi.org/10.1177/0149206311429379

Fauzan, F. (2013). Pengaruh religiusitas pada etika berbisnis (Studi pada RM. Padang di kota Malang). Jurnal Manajemen dan Kewirausahaan, 15(1), 53-64. https://doi.org/10.9744/jmk.15.1.53-64

Ferdinand, A. (2014). Structural equation modeling dalam penelitian manajemen: Aplikasi modelmodel rumit dalam penelitian untuk skripsi, tesis, dan disertasi doktor edisi $V$. Undip Press.

Frankl, V. E. (1984). Man's search for meaning: An introduction to logotherapy. Simon \& Schuster.

Glock, C. Y., \& Stark, R. (1965). Religion and society in tension. Rand McNally and Company. 
Hadjam, M. N. R., \& Nasiruddin, A. (2003). Peranan kesulitan ekonomi, kepuasan kerja, dan religiusitas terhadap kesejahteraan psikologis. Jurnal Psikologi, 30(2), 72-80.

Hamidah, T., \& Gamal, H. (2019). Hubungan religiusitas dengan psychological well-being pada anggota Satpamwal Denma Mabes TNI. IKRA-ITH HUMANIORA: Jurnal Sosial dan Humaniora, 3(2), 139-146. http://journals.upi-yai.ac.id/index.php/ikraithhumaniora/article/view/451.

Huber, S., \& Huber, O. W. (2012). The centrality of religiosity scale. Religions, 3(3), 710-724. https://doi.org/10.3390/rel3030710

International Standard Organization (2018). Goal 3: Good health and well-being ensure healthy lives and promote well-being for all at all ages. https://www.iso.org/sdg/SDG03.html

International Testing Commission. (2017). ITC guidelines for translating and adapting tests (Second edition). International Journal of Testing, 18(2), 101-134. https://doi.org/10.1080/15305058.2017.1398166

Isjoni, H. (2006). Membangun visi bersama: Aspek-aspek penting dalam reformasi pendidikan. Yayasan Obor Indonesia.

Karim, S. (2018). Hubungan antara dimensi big five personality dan religiusitas dengan subjective well-being karyawan. Jurnal Ecopsy, 56-42. http://journal.unika.ac.id/index.php/psi/article/viewFile/1338/850.

Kate, J. T., Koster, W. D, \& Waal, J. V. (2017). The effect of religiosity on life satisfaction in a secularized context: Assessing the relevance of believing and belonging. Review on Religious Research, 59(2), 135-155. https://doi.org/10.1007/s13644-016-0282-1

Koenig, H. G. (Ed.). (1998). Handbook of religion and mental health. Academic Press.

Koenig, H. G., \& Larson, D. B. (2001). Religion and mental health: Evidence for an association. International Review of Psychiatry, 13(2), 67-78. https://doi.org/10.1080/09540260124661

Luna-Arocas, R., \& Tang, T. L. P. (2004). The love of money, satisfaction, and the protestant work ethic: Money profiles among university professors in the USA and Spain. Journal of Business Ethics, 50(4), 329-354.

Margolis, S., Schwitzgebel, E., Ozer, D. J., \& Lyubomirsky, S. (2018). A new measure of life satisfaction: The riverside life satisfaction scale. Journal of Personality Assessment, 101(6), 621-630. https://doi.org/10.1080/00223891.2018.1464457

Meyers, M. C., Adams, B. G., Sekaja, L., Buzea, C., Cazan, A. M., Gotea, M., Stefenel, D., \& van Woerkom, M. (2018). Perceived organizational support for the use of employees' strengths 
and employee well-being: A cross-country comparison. Journal of Happiness Studies, 20, 1825-1841. https://doi.org/10.1007/s10902-018-0026-8

Mustafa, Z., \& Wijaya, T. (2012). Panduan teknik statistik SEM \& PLS dengan SPSS Amos. Cahaya Atma Pustaka.

Neal, J. (Ed.). (2012). Handbook of faith and spirituality in the workplace: Emerging research and practice. Springer Science \& Business Media.

NEF Consulting. (2014). Wellbeing at work: A review of the literature [Research report]. NEF Foundation. https://www.nefconsulting.com/wp-content/uploads/2014/04/Well-being-atWork-final-with-links.pdf

Otok, B. W., Guritno, S., Subanar, S., \& Haryatmi, S. (2017). Mengatasi penyimpangan asumsi normalitas pada pemodelan persamaan struktural menggunakan bootstrap. Jurnal Widya Manajemen dan Akuntansi, 7(2), 217-230.

Puente-Díaz, R., \& Cavazos, A. J. (2013). Personality factors, affect, and autonomy support as predictors of life satisfaction. Universitas Psychologica, 12(1), 41-53.

Rhoades, L., \& Eisenberger, R. (2002). Perceived organizational support: A review of the literature. Journal of Applied Psychology, 87(4), 698-714. https://doi.org/10.1037/00219010.87.4.698

Roemer, A., \& Harris, C. (2018). Perceived organizational support and well-being: The role of psychological capital as a mediator. SA Journal of Industrial Psychology, 44, a1539. https://doi.org/10.4102/sajip.v44i0.1539

Saliyo, Koentjoro, \& Subandi. (2017). The influence of religiosity, meaning of life towards subjective well-being of participants Naqsabandiyah Kholidiyah tarekat in Kebumen Indonesia. IOSR Journal Of Humanities And Social Science (IOSR-JHSS), 22(4), 34-43. http://www.iosrjournals.org/iosr-jhss/papers/Vol.\%2022\%20Issue4/Version3/D2204033443.pdf

Sarwono, J., \& Narimawati, U. (2015). Membuat skripsi, tesis, dan disertasi dengan Partial Least Square SEM (PLS-SEM). Andi.

Shyim, E. C., \& Korb, K. A. (2016). Factors contributing to the life satisfaction of secondary school teachers in Jos North LGA. Journal of Educational Foundations, 6, 27-36. https://www.ajol.info/index.php/jef/article/view/169594

Sperber, A. D. (2004). Translation and validation of study instruments for cross-cultural research. Gastroenterology, 126, S124-S128. https://doi.org/10.1053/j.gastro.2003.10.016. 
Stark, R., \& Glock, C. Y. (1968). American piety, patterns of religious commitment. University of California Press.

Steger, M. F., \& Dik, B. J. (2009). If one is searching for meaning in life, does meaning in work help? Applied Psychology: Health and Well-Being, 1(3), 303-320.

Steger, M. F., Dik, B. J., \& Duffy, R. D. (2012). Measuring meaningful work: The Work and Meaning Inventory (WAMI). Journal of Career Assessment, 20(3), 322-337. https://doi.org/10.1177/1069072711436160

Steger, M. F., Dik, B. J., \& Shim, Y. (2012). Assessing meaning and satisfaction at work. In S. J. Lopez (Ed.), The Oxford handbook of positive psychology assessment (2nd ed.) (pp. 1-11). Oxford University Press.

Sukarsa, I. M. (2010, Agustus 16). Wacana ekonomi spiritual di tengah pergulatan mashab ekonomi dan implementasinya di Bali [Paper presentation]. Seminar Internasional "Bali Sebagai Tempat Konservasi Budaya Spiritual”, Institut Hindu Dharma Negeri Denpasar.

Valentine, S., Martin, M. G., \& Sandra, B. R. (2006). Employee job response as a function of ethical context and perceived organization support. Journal of Business Research, 59(5), 582-588. https://doi.org/10.1016/j.jbusres.2005.06.004

Van Wingerden, J., \& Van der Stoep, J. J. (2017). The role of meaningful work in employees' work related and general well-being. International Journal of Human Resource Studies, 7(4), 2337. https://doi.org/10.5296/ijhrs.v7i4.11611

Worley, J. A., Fuqua, D. R., \& Hellman, C. M. (2009). The survey of perceived organizational support: Which measure should we use? SA Journal of Industrial Psychology, 35(1), 112115. https://doi.org/10.4102/sajip.v44i0.1539

Zhai, Q., Wang, S., \& Weadon, H. (2017). Thriving at work as a mediator of the relationship between workplace support and life satisfaction. Journal of Management \& Organization, 26(2), 168-184. https://doi.org/10.1017/jmo.2017.62

Zhou, M., \& Lin, W. (2016). Adaptability and life satisfaction: The moderating role of social support. Frontiers in Psychology, 7, 1134. https://doi.org/10.3389/fpsyg.2016.01134 